\title{
ANALYSIS OF THE IMPACT OF COMPETENCE AND CONSIDERATIONS MARKET WORK TOWARD ACCOUNTANT CAREERS ON POLIMDO ACCOUNTING STUDENTS
}

\author{
Esrie A.N Limpeleh, Nixon Sondakh, Rolina E. Manggopa, Selvie. J. Nangoy \\ Department Of Accounting, Polytechnic of Manado Country \\ DOI: 10.31364/SCIRJ/v7.i10.2019.P1019707 \\ http://dx.doi.org/10.31364/SCIRJ/v7.i10.2019.P1019707
}

\begin{abstract}
The purpose of this study is to determine the impact of competence, and labor market considerations on accountants' career choices. The research method used is quantitative research. This method is a scientific method because it fulfills scientific principles, namely: empirical, objective, measurable, rational, and systematic. This method is also called the discovery method, because with this method can be found and developed a variety of new science and technology. This method is called quantitative method because the research data is in the form of numbers and analysis using statistics, and is supported by interviews, surveys, questionnaires and so on. The results showed that accepting Ha1: there was an influence of competence on accountants 'career choices, and rejecting Ho1: Competence had no effect on accountants' career choices. Correlation and Regression of Competency Variables on Accountant's Career Options. The value of $\mathrm{R}$ which is at 0.538 , then the value of 0.538 shows, that the correlation between the independent variables Competency (X1), with the dependent variable Career Options (Y), a close relationship occurs because the value approaches 1. Receive Ha2: there is an influence of market considerations employment of accountants' career choices. And refuse Ho2: job market considerations have no effect on accountants' career choices. Correlation and regression of labor market considerations variables to accountants' career choices. A greater value of $\mathrm{R}$ indicates a stronger relationship, then a value of 0.656 indicates that a strong positive, where the relationship between variables $\mathrm{X} 2$, and $\mathrm{Y}$ has a close relationship between labor market considerations (X2), and Career Options Accountants (Y) have a positive relationship with a good level of closeness Accepting Ha3: competence and labor market considerations influence the accountant's career choice, and reject Ho3: competence and labor market considerations, do not affect the career choice of accountants. Correlation and regression of competency variables, and labor market considerations towards the choice of accountants' career choices $\mathrm{R}$ values are greater, showing a stronger relationship, then with a value of 0.726 shows that a strong positive, where the relationship between variables X1, X2 and $\mathrm{Y}$ have a close relationship. So between competence (X1), and labor market considerations (X2), and Career Options Accountants (Y) have a positive relationship with a good level of closeness.
\end{abstract}

Keywords: Career, Market Considerations, Competence

\section{Introduction}

Career is a job that has a good impact on the future. Career choices alone can be influenced by several factors, such as one's interactions with culture, friends, parents, in the hope of success in the future. According to Holland (1979) in Akbar (2011) individuals are attracted to a particular career because of their personality, and the various variables that underlie it. However, in today's career selection career, it is not an easy thing. Given the current development of the business world, or employment that seriously gives a special classification to every job seeker, who wants to enter the workforce. In other words, everyone must have competence in the type of career they choose.

Besides competence, there are other factors that can influence career choices, namely labor market considerations. Job market considerations are things considered by someone in choosing a job, because every job has opportunities, and opportunities that are different, professions that have a broad labor market, will be more desirable than professions that have a small labor market. Nowadays, career is a very important aspect of life, so career selection becomes an important point in the journey of life of every person today, coupled with the development of the current era, which requires each person to be competitive, in order to get a career as desired. With a career someone can make a big contribution, not only for themselves but also for the purpose of life of others. Careers are sequences of one's work experience over a period of time. Nowadays, everyone's dreams and hopes are to have a career. What's more, those who are students, certainly want to have a career that can guarantee their lives in the future.

Talking about the career choice of an accountant, which is a profession of someone who has an accounting education background, and has completed studies at one of the colleges both academia and vocational colleges. As stated in Law No. 34 of 1954, the use of an accountant's degree requires that an accountant's degree can only be used for those who have completed their education from tertiary institutions. At the Polimdo tertiary institution, especially in the accounting department, it applies three study programs, namely D3 accounting, D4 financial accounting and D3 tax accounting, this is to facilitate prospective students 
who want to enter, and study in Polimdo accounting majors to choose the study program in accordance with what they want. . With the hope that students will be able to work in accordance with the study program they are working on. But in terms of accountants' career choices, sometimes an accounting student has to adjust between their competencies and job market considerations in order to get an accountant's career, as he wants. Therefore, the authors in this case are interested in conducting a study, related to the influence of competence and labor market considerations on the career choices of accountants by accounting students in Polimdo.

Based on the foregoing, the author wishes to examine the extent of the impact of competence and labor market considerations on accountants' career choices in accounting students at Polimdo because many of the occupations of professions or occupations differ from educational backgrounds. In this connection, competence should be the background to be applied in the world of work. Meanwhile, if you see the progress of the world today, many companies are more likely to accept workers who are ready to use. This illustrates that there are other factors that cause a person to choose a career, in this case labor market considerations. The reason for choosing objects in accounting students at Polimdo, is due to several things, among others, researchers are easy to obtain data, and research costs are not large. Based on the above background, the following problem formulations can be made: Does the competence and consideration of the labor market affect the career choices of accountants?

\section{Research Methods}

The research method used is quantitative research. This method is a scientific method because it fulfills scientific principles, namely: empirical, objective, measurable, rational, and systematic. This method is also called the discovery method, because with this method can be found and developed a variety of new science and technology. This method is called quantitative method because the research data is in the form of numbers and analysis using statistics, and is supported by interviews, surveys, questionnaires and so on.

\subsection{Population and Sample}

1. Population

Table 2.1. Details of Student Population in Semester 6 and Semester 8

\begin{tabular}{|c|l|c|}
\hline Number & Population & Amount \\
\hline 1. & Semester 8 Student D4, Financial Accounting & 137 \\
\hline 2. & Semester 6 Student D3, Accounting & 38 \\
\hline \multicolumn{2}{|c|}{ TOTAL } & $\mathbf{1 7 5}$ \\
\hline
\end{tabular}

\section{Sample}

The number of respondents in this research was determined as many as 175 students or all students from Semester 6 D3 accounting and semester 8 D4 financial accounting on the grounds because the population is not too broad, and can still be reached by researchers. In addition, the characteristics of respondents in this case the competence of each student is different seen from the cumulative achievement index. Therefore, the researchers took the initiative to take the entire population as respondents.

\subsection{Data Measurement Tool}

This research uses the SPSS (statistical product and service solution) version 23 measurement tool. To measure the results of the questionnaire, this study uses 2 independent variables influencing accountants' career choices. The independent variables are:

1. Competence

2. Job market considerations

Scale options with formats such as:

1. Option $1=$ Strongly disagree with a score of 1

2. Option $2=$ Disagree with a score of 2

3. Option $3=$ Agree to be given a score of 3

4. Option $4=$ Strongly Agree to be given a score of 4

5. Option $5=$ Very Agree Once given a score of 5

\subsection{Data analysis technique}


This analysis uses the SPSS program package (statistical product and service solution) version 23. Furthermore, testing is carried out for the factors that affect students' interests in the career selection of accountants or non-accountants.

1. Validity test

$$
\begin{array}{lr} 
& \mathrm{n}\left(\sum \cdot \mathrm{xy}\right)-\left(\sum \mathrm{X}\right) \cdot\left(\sum \mathrm{Y}\right) \\
{ }^{\mathrm{r}} \text { count } & =\sqrt{\left(\left\{\cdot \sum x^{2}-\left(\sum x\right)^{2}\right\} \cdot\left\{n \cdot \sum y^{2}-\left(\sum y\right)^{2}\right\}\right.} \\
\text { Where : } & \\
\text { Rcount } & =\text { Correlation coefficient } \\
\sum \mathrm{Xi} & =\text { Number of item scores } \\
\sum_{\mathrm{N}}^{\mathrm{Yi}} & =\text { Total score (all items) } \\
\mathrm{N} & =\text { Number of respondents }
\end{array}
$$

2. Reliability test

Relability test is a tool to measure a questionnaire which is an indicator of a variable or construct. The statement item is said to be reliable, if people's answers to the statement are consistent, whereas according to Priyatno (2012), reliability of less than 0.6 is less good, while 0.7 is acceptable and above 0.8 is good.

\section{Normality Test}

Normality test is used to test whether the regression model has a normal distribution or not. Basic decision making can be done based on probability (Asymtotic significance), namely:

1) If the probability is $>0.05$ then the distribution of the population is normal

2) If the probability is $<0.05$, then the population is not normally distributed visually. Tests can also be performed using the normal probability plots drawing method in IBM SPSS Statistics 20. The basis for decision making is as follows:

(a) If the data spreads around the diagonal line and follows the direction of the diagonal line, it can be concluded that the regression model meets the normality assumption.

(b) If the data spreads far from the diagonal line and does not follow the direction of the diagonal line, it can be concluded that the regression model does not meet the assumption of normality.

4. Hypothesis testing

Data analysis was performed using SPSS (statistical product and service solution) programs. The analytical tool that will be used in this research is multiple linear regression. Hypothesis testing is done by using multiple linear regression methods that aim to test the relationship of influence between one variable against another variable. The equation can be described as follows:

Information :

$$
\mathrm{Y}=\mathrm{a}+\beta_{1} \mathrm{X}_{1}+\beta_{2} \mathrm{X}_{2}+\mathrm{e}
$$

Y : Career choice of accountant

a : Constants

$\mathrm{X}_{1} \quad$ : Accounting Competency Ability

$\mathrm{X}_{2} \quad$ : Labor Market Considerations

$\beta_{1}, \beta_{2}$ : Regression Coefficient

e : error

Linearity can only be applied to multiple regression because it has more than one independent variable, a multiple regression model is said to be linear if it meets linearity requirements, such as data normality (both individually and models) autocorrelation, heteroscedasticity.

\section{F test (simultaneous testing)}

The $\mathrm{F}$ test is a simultaneous regression relationship test which aims to determine whether all independent variables together have a significant influence on the dependent variable, Arikunto (2002). The testing steps with the F Test are as follows:

1) Determine the level of significance of $\alpha=5 \%$

Determining the significance level of $0.05 \%$ or $5 \%$ means that most likely the results of the conclusion have a $95 \%$ profitability or $5 \%$ error tolerance.

2) Calculating the F-test

$$
{ }^{\mathrm{r}} \text { count }=\frac{R^{2} / k}{\left(1-R^{2}\right) /(n-k-1)}
$$

Information :

$\mathrm{R}^{2}$ : The coefficient of joint determination

$\mathrm{k} \quad$ : Number of independent variables

n : Number of Samples 
3) Decision making criteria

Ho is rejected if $\mathrm{F}$ statistic $<0,05$ atau $\mathrm{F}_{\text {count }}>\mathrm{F}_{\text {table }}$

Ho is rejected if $\mathrm{F}$ statistic $>0,05$ atau $\mathrm{F}_{\text {count }}<\mathrm{F}_{\text {table }}$ of $\mathrm{F}$ table values is obtained from:

df1 (numerator) $=$ Number of independent variables

df2 (Denominator) = n-k-1

Information :

$\mathrm{n}$ : Number of Observations

$\mathrm{k}$ : Independent variable

6. T test (partial test)

$\mathrm{T}$ test is used to test the hypothesis partially to show the effect of each independent variable individually on the dependent variable. $\mathrm{T}$ test is a test of the regression coefficients of each independent variable on the dependent variable. The testing steps using the $t$ test are as follows:

$$
\text { r count }=\frac{\sqrt{n-2}}{\sqrt{1-r^{2}}}
$$

Where :

$\mathrm{t}=$ tcount value

$\mathrm{r}=$ correlation coefficient results $\mathrm{r}$ count

$\mathrm{n}=$ number of respondents

Distribution (table $\mathrm{t}$ ) for $\alpha=0.05$ and degrees of freedom $(\mathrm{dk}=\mathrm{n}-2)$. Decision rule: if tcount $>$ ttable means valid otherwise tcount $<$ ttable means invalid.

If the instrument is valid, then the interpretation criteria regarding the correlation index (r) are as follows:

Between 0,800 to 1,000 : very high

Between 0,600 to 0,799 : high

Between 0,400 to 0,599 ; high enough

Between 0,200 to 0,399 ; low

Between 0,000 to 0,100 : very low (invalid)

\section{Discussion}

\subsection{Respondents}

\begin{tabular}{|c|c|c|c|c|c|}
\hline \multirow[b]{3}{*}{ Number } & \multirow[b]{3}{*}{ Respondents } & \multirow{2}{*}{\multicolumn{4}{|c|}{ Questionnaire }} \\
\hline & & & & & \\
\hline & & $\begin{array}{c}\text { Spread } \\
\text { out }\end{array}$ & Back & Fall & Processed \\
\hline 1. & $\begin{array}{lccc}\text { Accounting Student Semester } 8, & \text { D4 } \\
\text { Financial Accounting Study Program } & \\
\end{array}$ & 137 & 134 & 6 & 128 \\
\hline 2. & $\begin{array}{l}\text { Accounting Student Semester } 6, \\
\text { Accounting Study Program }\end{array}$ & 38 & 36 & 4 & 32 \\
\hline
\end{tabular}

Table 3.3 Description of Respondents by Gender

\begin{tabular}{|c|l|c|c|c|}
\hline Number & \multicolumn{1}{|c|}{ Respondents } & Male & Female & Amount \\
\hline 1. & Semester 8 Student & 30 & 98 & 128 \\
\hline 2. & Semester 6 Student & 10 & 22 & 32 \\
\hline
\end{tabular}

\subsection{Preliminary Analysis}

The quality tests used are validity, reliability and normality tests. In this validity test the researchers took a sample of 30 respondents with the test results in table 3.4 as follows:

Table 3.4 Preliminary Validity Test

\begin{tabular}{|c|c|c|c|c|}
\hline Daftar Pernyataan & N & Produk Moment (R) & Validitas & Information \\
\hline Competence : & & & & \\
\hline Statement 1 & 30 & 0,361 & 0,482 & Valid \\
\hline Statement 2 & 30 & 0,361 & 0,467 & Valid \\
\hline Statement 3 & 30 & 0,361 & 0,415 & Valid \\
\hline Statement 4 & 30 & 0,361 & 0,384 & Valid \\
\hline Statement 5 & 30 & 0,361 & 0,400 & Valid \\
\hline
\end{tabular}




\begin{tabular}{|c|c|c|c|c|}
\hline Statement 6 & 30 & 0,361 & 0,349 & Invalid \\
\hline Statement 7 & 30 & 0,361 & 0,411 & Valid \\
\hline Statement 8 & 30 & 0,361 & 0,466 & Valid \\
\hline \multicolumn{5}{|c|}{ Job Market Considerations: } \\
\hline $\begin{array}{r}\text { Statement } 9 \\
\end{array}$ & 30 & 0,361 & 0,581 & Valid \\
\hline Statement 10 & 30 & 0,361 & 0,368 & Valid \\
\hline Statement 11 & 30 & 0,361 & 0,361 & Valid \\
\hline Statement 12 & 30 & 0,361 & 0,388 & Valid \\
\hline Statement 13 & 30 & 0,361 & $-0,043$ & Invalid \\
\hline Statement 14 & 30 & 0,361 & 0,581 & Valid \\
\hline Statement 15 & 30 & 0,361 & 0,483 & Valid \\
\hline Statement 16 & 30 & 0,361 & 0,482 & Valid \\
\hline \multicolumn{5}{|c|}{ Accountant Career Options: } \\
\hline Statement 17 & 30 & 0,361 & 0,444 & Valid \\
\hline Statement 18 & 30 & 0,361 & 0,482 & Valid \\
\hline Statement 19 & 30 & 0,361 & 0,120 & Invalid \\
\hline Statement 20 & 30 & 0,361 & 0,306 & Invalid \\
\hline Statement 21 & 30 & 0,361 & 0,527 & Valid \\
\hline Statement 22 & 30 & 0,361 & 0,620 & Valid \\
\hline Statement 23 & 30 & 0,361 & 0,387 & Valid \\
\hline Statement 24 & 30 & 0,361 & 0,556 & Valid \\
\hline Statement 25 & 30 & 0,361 & 0,474 & Valid \\
\hline Statement 26 & 30 & 0,361 & 0,561 & Valid \\
\hline Statement 27 & 30 & 0,361 & 0,330 & Invalid \\
\hline Statement 28 & 30 & 0,361 & 0,275 & Invalid \\
\hline Statement 29 & 30 & 0,361 & 0,239 & Invalid \\
\hline Statement 30 & 30 & 0,361 & 0,257 & Invalid \\
\hline
\end{tabular}

Source: Processed Data, SPSS 23

Based on the validity test table above, it can be concluded that of the 30 statements in the questionnaire tested for 30 respondents there were 8 statements that had r-count values <r-table, therefore 8 of these statements were declared invalid, and would not be included again in the questionnaire for testing with real respondents. Apart from that, the 8 invalid statements contained 22 statements which in the validity test table were declared valid because the value of $r$-count $>$ r-table.

\subsection{Test Validity, Reliability and Normality}

\section{Validity test}

Table 3.5 Test the Validity of Competency Variables (X1)

\begin{tabular}{|c|c|c|c|c|}
\hline List of Statements & N & Produk Moment (R) & Validity & Information \\
\hline Competence : & & & & \\
\hline Statement 1 & 100 & 0,148 & 0,340 & Valid \\
\hline Statement 2 & 100 & 0,148 & 0,266 & Valid \\
\hline Statement 3 & 100 & 0,148 & 0,337 & Valid \\
\hline Statement 4 & 100 & 0,148 & 0,301 & Valid \\
\hline Statement 5 & 100 & 0,148 & 0,485 & Valid \\
\hline Statement 7 & 100 & 0,148 & 0,374 & Valid \\
\hline Statement 8 & 100 & 0,148 & 0,399 & Valid \\
\hline
\end{tabular}

Source: SPSS Processed Data 23.

Table 3.6 Test the Validity of Labor Market Consideration Variables (X2)

\begin{tabular}{|c|c|c|c|c|}
\hline \multicolumn{1}{|c|}{ List of Statements } & N & Moment Products (R) & Validity & Information \\
\hline $\begin{array}{l}\text { Job Market } \\
\text { Considerations: }\end{array}$ & & & & \\
\hline Statement 9 & 100 & 0,148 & 0,590 & Valid \\
\hline Statement 10 & 100 & 0,148 & 0,382 & Valid \\
\hline Statement 11 & 100 & 0,148 & 0,574 & Valid \\
\hline Statement 12 & 100 & 0,148 & 0,549 & Valid \\
\hline Statement 14 & 100 & 0,148 & 0,559 & Valid \\
\hline Statement 15 & 100 & 0,148 & 0,570 & Valid \\
\hline Statement 16 & 100 & 0,148 & 0,709 & Valid \\
\hline
\end{tabular}

Source: SPSS Processed Data 23. 


\begin{tabular}{|c|c|c|c|c|}
\hline List of Statement & $\mathbf{N}$ & Moment Product (R) & Validity & Information \\
\hline Career choice : & & & & \\
\hline Statement 17 & 100 & 0,148 & 0,572 & Valid \\
\hline Statement 18 & 100 & 0,148 & 0,409 & Valid \\
\hline Statement 21 & 100 & 0,148 & 0,606 & Valid \\
\hline Statement 22 & 100 & 0,148 & 0,560 & Valid \\
\hline Statement 23 & 100 & 0,148 & 0,466 & Valid \\
\hline Statement 24 & 100 & 0,148 & 0,525 & Valid \\
\hline Statement 25 & 100 & 0,148 & 0,487 & Valid \\
\hline Statement 26 & 100 & 0,148 & 0,545 & Valid \\
\hline
\end{tabular}

Source: SPSS Processed Data 23.

To measure the value of validity as listed in the table above, that is determined by looking at the value $\alpha=0.05$ with the number of respondents 175 in the moment product table obtained r-table value of 0.148 . If the result of the validity is above 0.148 , it is considered a statement item, or the instrument is valid. The results of the validity analysis for all instruments on each variable both the competency variable (X1), Job Market Considerations (X2), and career choice of accountants (Y) are all valid because all instruments are above 0.148 . So that the variables above are feasible to be used as research variables.

\section{Reliability Test}

Table 3.8 Reliability Test Results of Labor Market Consideration Variables (X2)

\begin{tabular}{|c|c|c|}
\hline Variable & Cronbach's Alpha & N Of Items \\
\hline Variable X & 0,641 & 7 \\
\hline
\end{tabular}

Source: SPSS Processed Data 23.

In table 3.8 it shows that the reliability coefficient for the Labor Market Consideration variable is at 0.641 or not less than 0.6 This means that the research instrument of competency variables and the Labor Market Consideration (X2) is declared Reliable.

Table 3.9 Reliability Test Results for the Career Selection Accountant Variable (Y)

\begin{tabular}{|c|c|c|}
\hline Variable & Cronbach's Alpha & N Of Items \\
\hline Pilihan Karir Akuntan (Y) & 0,621 & 8 \\
\hline
\end{tabular}

Source: SPSS Processed Data 23.3

In table 3.9 it shows that the reliability coefficient for the Accountant's Career Options variable is at 0.621 or not less than 0.6. This means that the research instrument variable Accountant's Career Options (Y) is declared Reliable.

\section{Output Normality Test}

Picture 3.1 Normal P -P Plot Of Standarized Residual Regression

Normal P-P Plot of Regression Standardized Residual

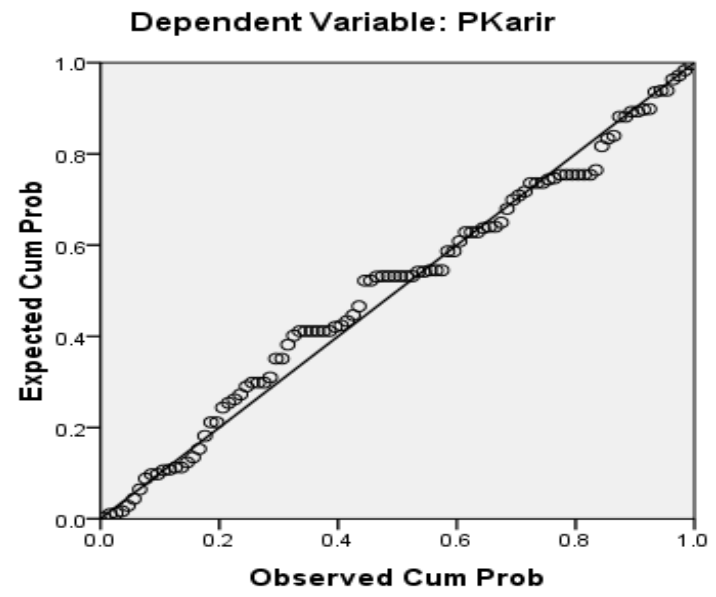



distributed

Based on picture 3.1 above, it can be seen that the points spread around the diagonal line, the residual value is normally

\subsection{Correlation and Regression Analysis Results}

The results of the analysis between the variables of Competency (X1), Job Market Considerations (X2) and Job Market Considerations (Y) can be seen in the table below:

Table 3.10 Table Model Summary

\begin{tabular}{|c|c|c|c|c|}
\hline Model & $\mathrm{R}$ & $\mathrm{R}$ Square & Adjusted R Square & $\begin{array}{c}\text { Std. Error of the } \\
\text { Estimate }\end{array}$ \\
\hline 1 & $.538^{\mathrm{a}}$ & .290 & .285 & 2.26908 \\
\hline
\end{tabular}

Source: SPSS Processed Data 23.

\section{Results of correlation analysis and simple regression between Competency (X1) and career choice (Y)}

The results of the regression analysis and correlation of the competency variable (X1) to Career Options (Y) are as follows: he number on R Square will be changed to the percent form. In table 3.10 above shows that R Square has a value of 0.290 or $29 \%$. that means the percentage contribution of the influence of the competency variable (X1) to the accountant's career choice (Y) is $29 \%$ while the rest is influenced by other variables. For clarity of the results of correlation and regression analysis in this study will be described as follows:

- Correlation coefficient: $r=0.538$

- The coefficient of determination: $\mathrm{r} 2=0.290$

- $\quad$ Regression coefficient: $Y=21,843+0.420 X$

The correlation coefficient value $\mathrm{R}=0.538$ shows that competence has a relationship with accountants' career choices. The coefficient of determination R Square $=0.290$ shows that career choices by accounting students in Polimdo $29 \%$ are influenced by competence, while the remaining $71 \%$ is influenced by other factors. It can be concluded that there is no significant effect between competencies on career choices because it is based on an R Square value of only 0.290. This means that if presented the effect of competence on career choices is only $29 \%$

\section{Results of correlation analysis and simple regression between Job Market Considerations (X2) and career choices (Y)}

The results of the regression analysis and explanation of the labor market considerations variable (X2) and accountant's Career Options (Y) are as follows:

Table 3.12 Model Summary

\begin{tabular}{|c|c|c|c|c|}
\hline Model & R & R Square & Adjusted R Square & Std. Error of the Estimate \\
\hline 1 & $.656^{\mathrm{a}}$ & .431 & .427 & 2.03188 \\
\hline
\end{tabular}

Source: SPSS Processed Data 23.

The summary output table shows the strength of the relationship between the independent variable (Independent Variable) and the dependent variable (Dependent Variable). $\mathrm{R}$ is a measure to measure correlation (closeness of the relationship between the dependent variable with the independent variable). The greater $\mathrm{R}$ value indicates a relationship, then a value of 0.656 indicates that the variables X2 and Y have a relationship.

R. Square or often called the coefficient of determination that serves to measure the effect of the independent variable on the dependent variable. The number on R Square will be changed to the percent form. R Square $=0.431$ means that $43.1 \%$ of accountants' career choices (Y) are influenced by labor market considerations (X2), the rest are influenced by other variables outside the research variable. 
For clarity of the results of the correlation analysis and regression between the labor market considerations variable (X2), the accountant's career choice (Y) in this study will be described as follows:

Correlation coefficient: $r=0.656$

The coefficient of determination: $\mathrm{r} 2=0.431$

Regression equation: $\mathrm{Y}=14,837+0.658 \mathrm{X}$

The correlation coefficient value of $r=0.656$ shows that the labor market considerations have a relationship with accountants' career choices. The coefficient of determination $\mathrm{r} 2=0.431$ shows that career choices by accounting students in Manado's state polytechnic $43.1 \%$ are influenced by the Labor Market Considerations while the remaining $56.9 \%$ is influenced by other factors. It can be concluded that there is a significant influence between job market considerations on the choice of accountants' careers by accounting students in polimdo. This can be seen from the R Square Value of 0.431 which means that if presented the effect of labor market considerations on the career choices of accountants that is equal to $43.1 \%$.

\section{Hasil analisis korelasi dan regresi antara Kompetensi (X1) dan Pertimbangan Pasar Kerja (X2) terhadap pilihan karir (Y)}

The results of the regression analysis and explanation of the competency variables and the labor market considerations (X2) of the Accountants' Career Options (Y) are as follows:

Table 3.14 Model Coefficients

\begin{tabular}{|c|c|c|c|c|c|c|}
\hline & \multirow[t]{2}{*}{ Model } & \multicolumn{2}{|c|}{$\begin{array}{l}\text { Unstandardized } \\
\text { Coefficients }\end{array}$} & \multirow{2}{*}{$\begin{array}{l}\text { Standardized } \\
\text { Coefficients } \\
\text { Beta }\end{array}$} & \multirow[t]{2}{*}{$\mathrm{T}$} & \multirow[t]{2}{*}{ Sig. } \\
\hline & & B & Std. Error & & & \\
\hline \multirow{3}{*}{1} & (Constant) & 10.593 & 1.842 & & 5.750 & .000 \\
\hline & Competence & .263 & .046 & .337 & 5.681 & .000 \\
\hline & PPK & .529 & .060 & .528 & 8.891 & .000 \\
\hline
\end{tabular}

Source: SPSS Processed Data 23.

The summary output table shows the strength of the relationship between the independent variable and the dependent variable. $\mathrm{R}$ is a measure to measure correlation (closeness of the relationship between the dependent variable with the independent variable). A greater $\mathrm{R}$ value indicates a stronger relationship, then a value of 0.726 indicates that the relationship between variables $\mathrm{X} 1, \mathrm{X} 2$ and $\mathrm{Y}$ has a relationship. So between competence (X1) and labor market considerations (X2) and Career Options Accountants (Y) have a good relationship.

$\mathrm{R}$ Square, often called the coefficient of determination, is a measure of the goodness of the regression equation. R Square $=0.527$ means $52.7 \%$ of accountants' career choices $(\mathrm{Y})$ are influenced by competence (X1) and labor market considerations (X2), the rest are influenced by other variables outside the research variable.

- For clarity of the results of correlation analysis and regression between competency variables (X1) and labor market considerations (X2) of the career choice of accountants (Y) in this study will be described as follows Correlation coefficient: $\mathrm{r}=0.726$

- $\quad$ The coefficient of determination: $\mathrm{r} 2=0.527$

- $\quad$ Regression equation: $\mathrm{Y}=10.107+0.261 \mathrm{X} 1+0.552 \mathrm{X} 2$ 
Table 3.15 Model Summary

\begin{tabular}{|c|c|c|c|c|}
\hline Model & $\mathrm{R}$ & $\mathrm{R}$ Square & Adjusted R Square & $\begin{array}{c}\text { Std. Error of the } \\
\text { Estimate }\end{array}$ \\
\hline 1 & $.726^{\mathrm{a}}$ & .527 & .517 & 1.81327 \\
\hline
\end{tabular}

Correlation coefficient $\mathrm{r}=0.726$ indicates competence, and labor market considerations have a relationship. The coefficient of determination $\mathrm{r} 2=0.527$ shows that career choices by accounting students in the Polytechnic of Manado $52.7 \%$ are influenced by competence and labor market considerations. While the remaining $47.3 \%$ is influenced by other factors. It can be concluded that there is a significant influence between competence and labor market considerations on the career choices of accountants by accounting students in the Polimdo.

\subsection{Hypothesis test}

Hypothesis testing in this study using SPSS (statistical product and service solution) analysis tool used in this study is multiple linear regression. Testing using multiple linear analysis is used to determine the effect or linear relationship between two or more independent variables with one dependent variable. The hypothesis of this study is stated as follows:

\section{Competence (H1)}

Ha1 : Competence Influences Accountant's Career Options

Ho1 : Competence Has No Effect on Career Options for Accountants

J ob Market Considerations (H2)

Ha2 : Job Market Considerations Influence Accountant's Career Options

Ho2 : Job Market Considerations Have No Effect on the Career Options of Accountants

Labor Market Competencies and Considerations (H3)

Ha3 : Competence and Job Market Considerations Influence Accountant's Career Options

Ho3 : Competence and Job Market Considerations Have No Effect on the Career Options of Accountants

Characteristics of hypothesis testing using multiple linear regression testing in this study is used to examine the effect between competency variables (X1) and Job Market Considerations (X2) on Career choice of Accountants (Y).

\section{Partial test results for Effect of Competence on Accountant's Career Options}

Following are the results of hypothesis testing between competencies and accountants' career choices

Table. 3.16 Coefficients ${ }^{\mathrm{a}}$

\begin{tabular}{|c|c|c|c|c|c|c|}
\hline \multirow{2}{*}{ Model } & \multicolumn{2}{|c|}{ Unstandardized Coefficients } & $\begin{array}{c}\text { Standardized } \\
\text { Coefficients }\end{array}$ & \multirow{2}{*}{$\mathrm{t}$} & \multirow{2}{*}{ Sig. } \\
\cline { 3 - 5 } & B & Std. Error & Beta & & .000 \\
\hline \multirow{2}{*}{1} & (Constant) & 21.843 & 1.636 & & 13.348 & .000 \\
\cline { 2 - 7 } & Competence & .420 & .052 & .538 & 8.031 & \\
\hline
\end{tabular}

Source: SPSS Processed Data 23.

Based on table 3.16 above, a t-count of 8031 is obtained. The t-table value can be seen in the statistical table for the significance of 0.05 with degrees of freedom or $\mathrm{df}=\mathrm{n}-\mathrm{k}-1$ or $160-2-1=157$. The results obtained for the $\mathrm{t}$-table are 1.974 (seen in the t-table attachment ). Test criteria, If t-count $>$ from t-table, Ho1 is rejected and Ha1 is accepted. So based on the results above it can be concluded that the value of t-count> t-table is 8.031>1.974 then Ha1 is accepted and Ho1 is rejected. So it can be concluded that competence influences the career choice of accountants by accounting students at Polimdo.

2. Partial Test Results for the influence of labor market considerations on accountants' career choices

The following are the results of testing the hypotheses between job market considerations and accountants' career choices. 
Table 3.17 Coefficients ${ }^{\mathrm{a}}$

\begin{tabular}{|c|c|c|c|c|c|c|}
\hline \multicolumn{2}{|c|}{ Model } & \multicolumn{2}{|c|}{ Unstandardized Coefficients } & $\begin{array}{c}\text { Standardized } \\
\text { Coefficients }\end{array}$ & \multirow{2}{*}{$\mathrm{T}$} & \multirow{2}{*}{ Sig. } \\
\cline { 3 - 5 } & & B & Std. Error & Beta & & \\
\hline \multirow{2}{*}{1} & (Constant) & 14.837 & 1.843 & & 8.051 & .000 \\
\cline { 2 - 7 } & PPK & .658 & .060 & .656 & 10.931 & .000 \\
\hline
\end{tabular}

Source: SPSS Processed Data 23.

Based on table 3.17 above, a tcount of 10.931 was obtained. The t-table value can be seen in the statistical table for the 0.05 significance with degrees of freedom or $\mathrm{df}=\mathrm{n}-\mathrm{k}-1$ or $160-2-1=157$. The results obtained for t-table, namely 1.974 (seen in appendix t- table). Test criteria If the tcount> t-table then Ho2 is rejected and Ha2 is accepted. So, based on the above results it can be concluded that the value of t-count $>\mathrm{t}$-table is 10.931>1.974 then Ha2 is accepted and Ho2 is rejected. So it can be concluded that competence influences the career choice of accountants by accounting students at Polimdo.

\section{Joint Test Results for the effect of competence and labor market considerations on accountants' career choices}

Table 3.18 ANOVA Hypothesis Test Output

\begin{tabular}{|c|c|c|c|c|c|c|}
\hline \multicolumn{2}{|c|}{ Model } & Sum of Squares & Df & Mean Square & F & Sig. \\
\hline \multirow{3}{*}{1} & Regression & 332.094 & 1 & 332.094 & 64.500 & $.000^{\mathrm{a}}$ \\
\cline { 2 - 9 } & Residual & 813.500 & 158 & 5.149 & & \\
\cline { 2 - 8 } & Total & 1145.594 & 159 & & & \\
\hline
\end{tabular}

Source: SPSS Processed Data 23.

Based on table 3.18 above, we get an F count of 64,500. The F table value can be seen in the statistical table for the 0.05 significance with degrees of freedom or $\mathrm{df}=\mathrm{n}-\mathrm{k}-1$ or $160-2-1=157$. The results obtained for the $\mathrm{F}$ table are 3.050 (seen in the appendix $\mathrm{F}$ table). Test criteria If F count $>$ from $\mathrm{F}$ table then Ho3 is rejected and Ha3 is accepted. So based on the results above it can be concluded that the calculated F value> F table is 64.500> 3.050 then Ha3 is accepted and Ho3 is rejected. So it can be concluded that the competence and consideration of the labor market affect the career choices of accountants by accounting students at Polimdo.

\section{CONCLUSION}

Based on the analysis of the data collected, conclusions can be drawn that can answer the research hypothesis. The conclusion is as follows:

1. Accept Ha1: There is an effect of competence on accountants 'career choices and reject Ho1: Competence has no effect on accountants' career choices.

2. Accepting Ha2: there is an influence of labor market considerations on accountants' career choices. And refuse Ho2: job market considerations have no effect on accountants' career choices.

3. Accepting Ha3: Job market competencies and considerations influence the choice of accountants 'careers and reject Ho3: labor market competencies and considerations have no effect on accountants' career choices.

As for the regression or correlation test of each variable the data shows as below:

1. Correlation and Regression of Competence Variables on Accountant's Career Options. R value which is at 0.538 , then the value of 0.538 shows that the correlation between the independent variable Competence (X1) with the dependent variable Career Options (Y) occurs a close relationship because the value is close to 1 . R. Square or often called the coefficient of determination Table 4.10 above shows that $\mathrm{R}$ Square has a value of 0.290 or $29 \%$. that means the percentage contribution of the influence of the competency variable (X1) to the accountant's career choice (Y) is $29 \%$ while the rest is influenced by other variables.

2. Correlation and regression of labor market considerations variables to accountants' career choices. A greater value of $\mathrm{R}$ indicates a stronger relationship, then a value of 0.656 shows that a strong positive where the relationship between variables $\mathrm{X} 2$ and $\mathrm{Y}$ has a close relationship between labor market considerations (X2) and Career Options Accountants (Y) have a positive relationship with the level of closeness well. R. Square, often called the coefficient of determination, is measuring 
the goodness of the regression equation. $\mathrm{R}$ Square $=0.431$ means that $43.1 \%$ of accountants' career choices $(\mathrm{Y})$ are influenced by labor market considerations (X2), the rest are influenced by other variables outside the research variable.

3. Correlation and Regression of competence variables and labor market considerations towards accountants' career choices Greater $\mathrm{R}$ values indicate a stronger relationship, then a value of 0.726 shows that a strong positive relationship between variables X1, X2 and Y has a close relationship. So between competence (X1) and labor market considerations (X2) and Career Options Accountants (Y) have a positive relationship with a good level of closeness. R. Square, often called the coefficient of determination, is measuring the goodness of the regression equation. $\mathrm{R}$ Square $=0.527$ means $52.7 \%$ of accountants' career choices (Y) are influenced by competence (X1) and labor market considerations (X2), the rest are influenced by other variables outside the research variable.

\section{REFERENCES}

Akbar, Hanifan.(2011). Career Selection Trends Based on Learning Styles High School Class XII students.

Andersen, W.(2012) Analysis of Perception Accounting students in choosing a profession as accounting. Thesis, Diponegoro University. Semarang

Anto Dajan.(2008). Introduction to Volume II Statistics :LP3ES

Asmoro dkk (2016). Factors that influence accounting students in career choices as accountants.

Bilson,Simamora.(2001). Winning the Market with Effective and Professional Marketing, First Edition. Jakarta: PT. Gramedia Pustaka Utama

Blau, M Peter. dkk (1987). Bureaucracy of Modern Society, Second Edition, first print, Ul- Press, Jakarta.

Danang Suyoto.(2013). Accounting Research Methodology.Bandung: PT Refika Aditama

Dariyo, Agoes. (2004). Developmental psychology : Dewa Muda. Jakarta:Grasindo

Eny, Kusriyati.(2008). Factors that influence the interest of accounting students in choosing a career in accounting

Greenberg, Jerald dan Baron, Robert A. (2000). Organizational behavior . Jakarta:Prentice Hall

Jumamik, (2007). Accounting Student Perceptions Regarding Factors That Influence Accountants' Career Selection. Universita Eleven March, Semarang.

Kunartinah. (2003). Factors that influence career selection as a public accountant

Kusuma, Perdana Gilang. (2011) Effect of Competence and Career Development on students' interest to follow the accounting profession

Lina Marliyah, dkk.(2004). Perceptions of parental support and teenage career decision making. Journal of Provitae, January 1 (1).

Mulyadi, (2013). Auditing, sixth edition. Jakarta. PT. salemba empat

Rahayu, Sri dkk. (2003). Accounting students' perceptions about factors that influence career

Setyawardani, Lydia.(2009). Junior and senior student perceptions of the accounting profession. Equity. Vol. 13 No. March 1, 2009

Soemarso, (2004). Accounting An Introduction. Issue Five Jakarta:Salemba Empat

Wijayanti, (2001). Factors That Influence Career Choices in Accounting Students. Thesis. Gadjah Mada University 